\title{
Trichomycterus igobi, a new catfish species from the rio Iguaçu drainage: the largest head in Trichomycteridae (Siluriformes: Trichomycteridae)
}

\author{
Wolmar B. Wosiacki ${ }^{1}$ and Mário de Pinna ${ }^{2}$
}

A new species of Trichomycterus is described for the rio Iguaçu drainage in Southern Brazil. Trichomycterus igobi, new species, is readily distinguishable from all other species currently in the genus by its extremely large head (23.8-26.8 \% SL), which is proportionally the largest head in any Trichomycteridae. That characteristic plus the relatively deep body result in a very short-bodied overall aspect, the most extremely such case in the genus Trichomycterus. Other diagnostic features that distinguish the new species from most or all of its congeners include a short caudal peduncle (15.4-19.7\% SL); an almost entirely cartilaginous second hypobranchial (with only vestigial ossification); a mesial expanded palatine ossification; a narrow cleithrum, falciform in shape; and the lack of a proximal posterior concavity on the third ceratobranchial. The new species seems to form a monophyletic group with $T$. stawiarski and other undescribed species (T. sp. C), also endemic to the rio Iguaçu. As putative synapomorphies, the three species share a rigid spine-like morphology of individual procurrent caudalfin rays, an extended area of dorsal caudal-fin procurrent rays, and numerous branchiostegal rays (ten or eleven).

Uma nova espécie de Trichomycterus é descrita para a bacia do rio Iguaçu, sul do Brasil. Trichomycterus igobi, nova espécie, é facilmente distinguida das outras espécies atualmente no gênero por sua cabeça extremamente grande (23.8-26.8\% SL), que é proporcionalmente a maior em Trichomycterinae e talvez em Trichomycteridae. Esta característica, em combinação com o corpo relativamente alto, resulta em um aspecto geral atacarracado que é o mais extremo no gênero Trichomycterus. Outras características que distinguem a nova espécie da maioria ou todas as outras espécies do gênero incluem o curto pedúnculo caudal (15.4-19.7 \% SL); segundo hipo-branquial quase inteiramente cartilaginoso (somente com ossificação vestigial); palatino expandido medialmente; cleitro estreito, de formato falciforme; e ausência de uma concavidade posterior no terceiro ceratobranquial. A nova espécie parece formar um grupo monofilético com T. stawiarski e outra espécie não descrita (T. sp. C), também endêmicas do rio Iguaçu. Como potenciais sinapomorfias, as três espécies compartilham uma morfologia rígida dos raios procurrentes caudais, que são semelhantes a espinhos; área estendida de distribuição de raios procurrentes caudais dorsais; e raios branquiostégios numerosos (10 ou 11).

Key words: Systematics, taxonomy, fishes, Trichomycterinae, Paraná Basin.

\section{Introduction}

Among the vast and relatively poorly-known Neotropical freshwater fish fauna, trichomycterids stand out as a particularly diverse and obscure group. The family includes unique trophic specializations, such as haematophagy in members of the subfamily Vandelliinae and lepidophagy in Stegophilinae. Their range of habitats is also remarkably diverse, including unusual freshwater habitats, such as sand, semi-temporary pools, high-altitude Andean streams and desolate creeks in Tierra del Fuego. Morphological variation in trichomycterids mirrors their ecological diversity, with body forms ranging from eel-like species of Glanapteryx to globose Sarcoglanis. Internal anatomy displays even greater diversity, with skeletal modifications sometimes so profound that even the identification of bone homologies is problematic for the non-specialist. Approximately half of all trichomycterids species, however, do not fall into those conspicuous categories and are represented by generalized predators of aquatic invertebrates, usually inhabiting fast-flowing rocky streams and with a rather uniform external body aspect. Most of those are included in the genus Trichomycterus, probably a non-monophyletic

${ }^{1}$ Setor de Ictiologia, Museu Paraense Emílio Goeldio - MPEG, Av. Magalhães Barata, 376, Caixa Postal 399, 66040-170 Belém, PA, Brazil. wolmar@museu-goeldi.br

${ }^{2}$ Departamento de Vertebrados, Museu de Zoologia da Universidade de São Paulo - MZUSP, Caixa Postal 42494, 04218-970 São Paulo, SP, Brazil.pinna@ib.usp.br 
group (Baskin, 1973; de Pinna 1989; Costa \& Bockamnn, 1993; and Wosiacki, 2002) which nonetheless includes 100 valid nominal species, with additional ones often described (de Pinna \& Wosiacki, 2003; Wosiacki \& de Pinna, 2007). The systematics of Trichomycterus is in a difficult state, for a variety of reasons. First, the latest published revision is almost 90 years old (Eigenmann, 1918) and is severely outdated. Second, the preference of species of the genus for fast-flowing headwaters in highlands often results in numerous isolated slightly-differentiated populations, whose specific status is hard to determine precisely. Third, there is sometimes pronounced intraspecific variation in color pattern ( $c f$. Arratia 1978: 171), one of the characters most commonly used to diagnose species of Trichomycterus. Fourth, descriptions of new species were, and still are, often published with little concern for already-named yet poorly-known forms, resulting in ever-growing nomenclatural confusion. Until such time as when the taxonomy of Trichomycterus is better understood, we believe that new species in the genus should be proposed only when supported by unambiguous character evidence.

In this paper, we present a new species assignable to the genus Trichomycterus which is markedly distinct from all other forms so far described. A number of conspicuous morphological characteristics set it apart from all others species as yet known in the genus. For instance, its very large head distinguishes it at once from all other species so far known in Trichomycterus, and in fact from all other trichomycterid. Other characters of external and internal morphology also unambiguously support its specific distinctiveness. The new form is the tenth species of Trichomycterus described from the rio Iguaçu, a drainage that contains an impressive radiation of the genus, which only recently received attention from fish systematics (Wosiacki \& Garavello, 2004; Wosiacki \& de Pinna, in press). Character evidence indicates that the new species is closely related to T. stawiarski and to a second new species, T. sp. C (Wosiacki \& de Pinna, in press), also from the rio Iguaçu.

\section{Material and Methods}

All measurements were taken point-to-point with calipers on the left side of specimens. Caudal peduncle length was measured from the base of the last anal-fin ray to the middle of caudal-fin base; caudal peduncle depth was taken at the vertical through the middle of its length; distance between pelvic-fin base and anus was measured from the base of the inner pelvic-fin ray to anterior margin of the anus; supraorbital pore distance was the distance between S6 pores. Remaining measurements followed Tchernavin (1944). Dorsal and anal-fin ray counts included all branched rays plus all unbranched rays visible in radiographs.

Specimens cleared and counterstained (c\&s) for cartilage and bone were prepared according to a modified version of the method of Dingerkus \& Uhler (1977). Radiographs of specimens were done with a Faxitron digital x-ray system, model MX-20. Vertebral counts did not include those in the Weberian complex and compound caudal centrum. Numbers of vertebrae and pleural ribs were taken from cleared and stained preparations and radiographs of alcoholic specimens. The nomenclature for latero-sensory canal system and associated pores followed Arratia \& Huaquin (1995).

Material studied in this paper is deposited in the following institutions: AMNH - American Museum of Natural History, New York; CAS - California Academy of Sciences, San Francisco; MCP - Museu de Ciências e Tecnologia da Pontifícia Universidade Católica do Rio Grande do Sul, Porto Alegre; MHNCI - Museu de História Natural Capão da Imbuia, Curitiba; MNRJ - Museu Nacional, Universidade Federal do Rio de Janeiro, Rio de Janeiro; MPEG - Museu Paraense Emílio Goeldi, Belém; MZUSP - Museu de Zoologia da Universidade de São Paulo, São Paulo; NUP - Núcleo de Pesquisa em Limnologia, Ictiologia e Aqüicultura, Maringá; UFRGS Universidade Federal do Rio Grande do Sul, Porto Alegre.

\section{Trichomycterus igobi, new species}

Figs. 1 and 2

Holotype. MPEG 13352 (90.1 mm SL), Brazil, Estado do Paraná, Município de Candói, rio Jordão above the hydroelectric dam of Santa Clara, Apr 2005, NUP team col.

Paratypes. NUP 4007, 2, 62.0-66.3 mm SL, Brazil, Estado do Paraná, Município de Candói, rio do Sobradinho (tributary to rio Jordão), 8 Apr 2005, NUP team col; MPEG 13353, 2, 72.4-82.7 mm SL, collected with NUP 4007; MZUSP 94842, 2, 72.1-86.6 mm SL, collected with NUP 4007; MZUSP 94843, 3, 63.0-89.8 mm SL, Brazil, Estado do Paraná, Município de Candói, rio Jordão, no date, NUP team col; MPEG 13354, 1c\&s, $70.9 \mathrm{~mm} \mathrm{SL}$, collected with MZUSP 94843.

Diagnosis. Trichomycterus igobi is distinguishable from all other species currently in Trichomycterus by its large head $(23.8-26.8 \% \mathrm{SL})$, which is proportionally the largest head in any Trichomycteridae. Other diagnostic features that distinguish the new species from most or all of its congeners include an almost entirely cartilaginous second hypobranchial (with only vestigial ossification); a mesially expanded palatine ossification; a narrow cleithrum, falciform in shape; and the lack of a proximal posterior concavity on the third ceratobranchial. The rigid spine-like morphology of individual procurrent rays of the caudal fin, the extension of the dorsal caudal-fin procurrent ray series (extending for ten neural spine tips), and the presence of ten or eleven branchiostegal rays each distinguish $T$. igobi from all congeners except $T$. stawiarski and T. sp. C (see Discussion). Other characters shared with various other species of Trichomycterus yet useful for identification include a dorsal fin located on a concavity on dorsal profile of trunk; the short caudal peduncle (15.4$19.7 \% \mathrm{SL})$; and the first anal-fin ray base posterior to the vertical through the base of the last dorsal-fin ray. 


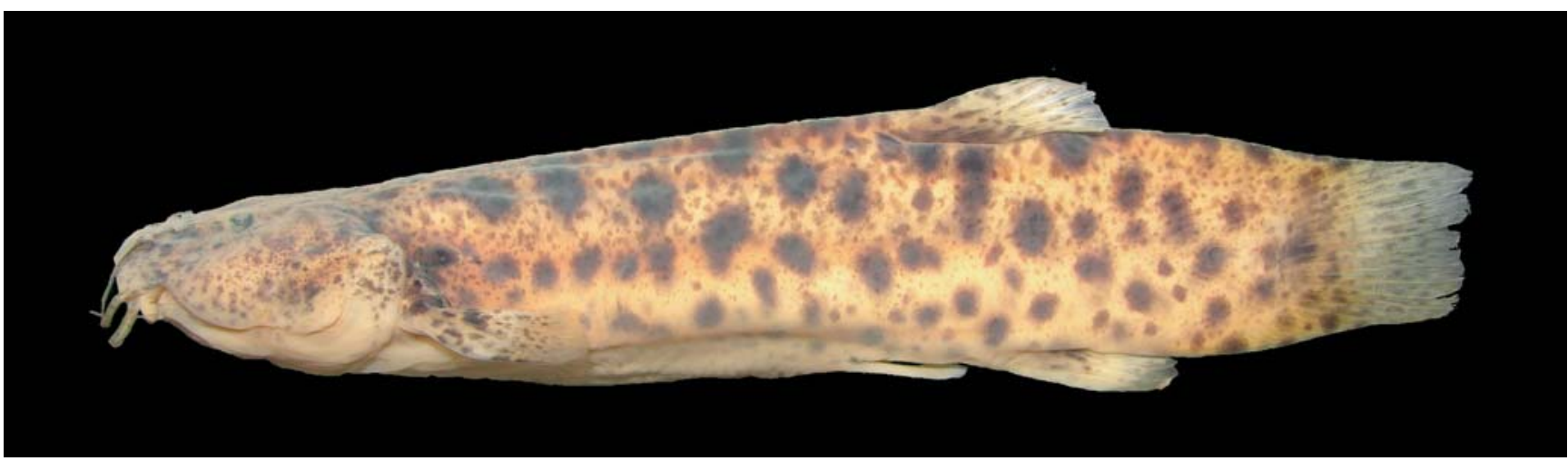

Fig. 1. Trichomycterus igobi, MPEG 13352, holotype, $90.1 \mathrm{~mm}$ SL. Lateral view of right side (photograph inverted).

Description. Morphometric data for holotype and paratypes given in Table 1.

Body short, rounded at level of pectoral girdle and gradually more compressed posteriorly. Dorsal profile of trunk straight or slightly convex, ventral profile gently convex. Dorsal and ventral profiles of caudal peduncle slightly convex. Integument thick and opaque, especially over dorsal-, anal- and pectoral-fin bases. Small papillae visible under stereomicroscope over surface of body; papillae larger and more densely concentrated over oral surface of lips. Head large, longer than wide, depressed. Head width larger than maximum body width. Snout broad, convex in dorsal view. Dorsal profile of head straight in lateral view; ventral profile slightly convex. Interorbital region flat. Lateral portion of head swollen by well-developed jaw muscles. Eyes round, dorso-laterally oriented, slightly converging anteriorly towards midline. Orbital rim not free. Skin covering eye thin and transparent. Anterior nostrils smaller than eye, separated by space approximately equal to interorbital, surrounded by fleshy flap of integument posterolaterally continuous with nasal barbel. Posterior nostrils smaller and more closely positioned to each other than anterior ones, partially surrounded anteriorly, laterally and medially by thin flap of skin. Branchial membranes thick, narrowly united to isthmus anteriorly. Gill opening wide, not constricted. Ten or eleven (modally ten) branchiostegal rays, most of which clearly visible externally.

Mouth wide, subterminal, with corners laterally oriented. Upper and lower lips fleshy, similar-sized. Lower lip with large fleshy lobes located posteromedially to origin of rictal barbels.

Barbels short and thin, gradually narrowing to fine tips. Nasal barbels flat and narrow, posteriorly reaching middle of eyes. Origin of nasal barbels on posterolateral portion of integument flap around anterior nostril. Maxillary and rictal barbels thin and moderately long, both reaching vertical through posterior margin of eyes.

Pectoral fin narrow, with rounded margin. Pectoral-fin rays i, 7, first one longest, unbranched, not prolonged as filament. Dorsal fin round, with i,6-7 rays (modally i,7, including holotype), second and third longest. Anal fin shorter and narrower than dorsal fin. Base of first anal-fin ray located posterior to vertical through base of last dorsal-fin ray. Anal-fin

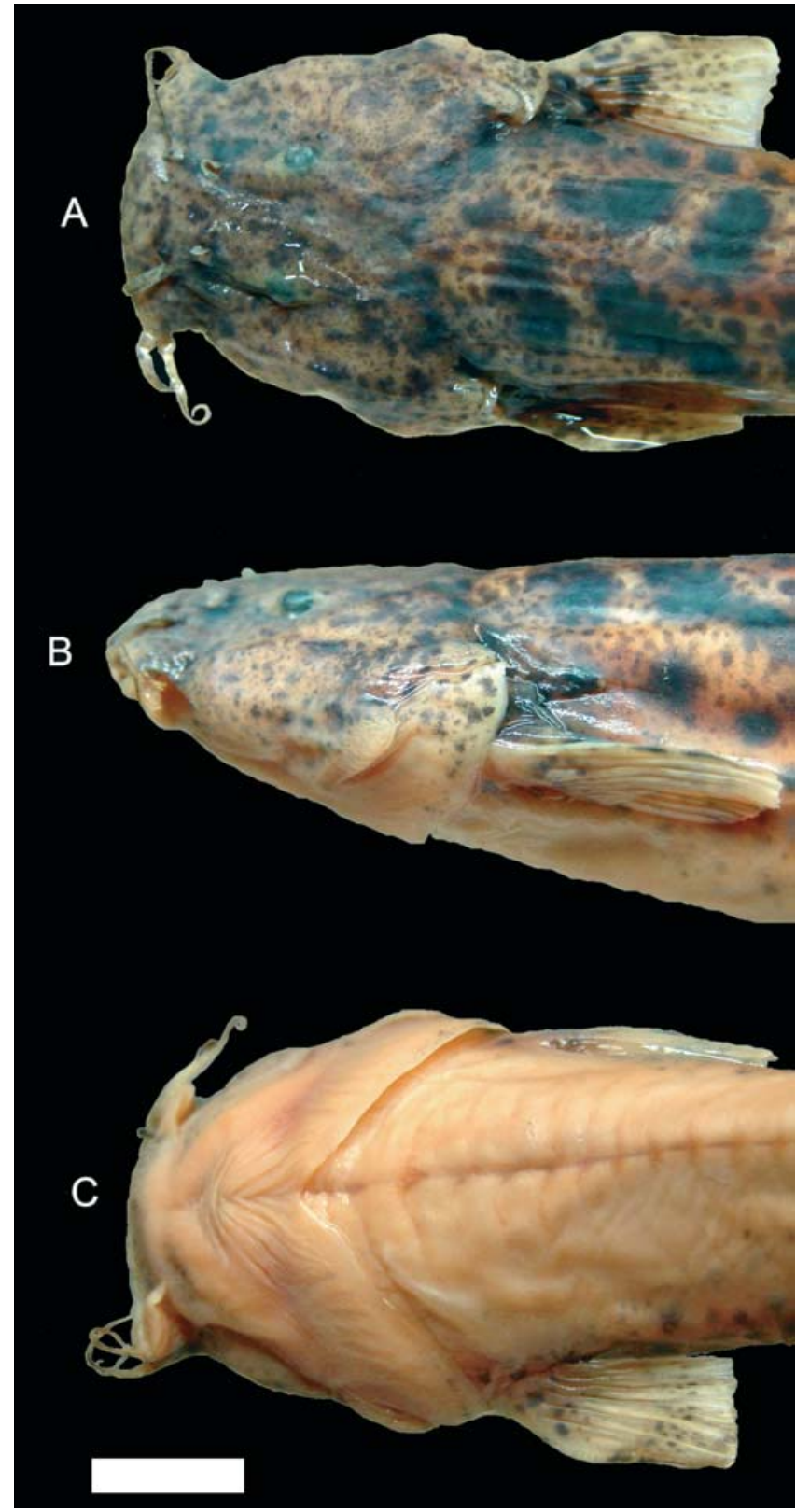

Fig. 2. Head of Trichomycterus igobi, MPEG 13352, holotype, $90.1 \mathrm{~mm}$ SL: A) Dorsal view; B) Lateral view; C) Ventral view. Scale bar $=1 \mathrm{~cm}$. 
rays i-ii,5, second ray longest. Pelvic fin with i,4 rays, second one longest. Pelvic-fin base anterior to dorsal-fin origin; inner rays of contralateral pelvic-fin not overlapping when in repose; distal part of fin covering urogenital opening. Caudal fin truncate with straight corners; distal margin slightly deeper than fin base; $6+7$ principal rays.

Opercular patch of odontodes very small, with 9-12 short, thin, straight odontodes with thick tips. Interopercular patch of odontodes with nine short, thick, conic odontodes arranged in a single main series, with additional odontodes posteriorly.

Cephalic sensory canals including complete supraorbital canal and incomplete infraorbital canal. Infraorbital restricted to posterior region corresponding to pores i10 and i11. Supraorbital pores S1, S3 and S6. Two paired pores S6. Laterosensory canal reduced on trunk, comprising two pores at vertical through middle of pectoral fin. Vertebra 37, ribs 13 pairs, first thickest, 6th and 7th longest, last rib rudimentary. Dorsal-fin pterygiophores 8 , first one inserting anterior to neural spine of 17 th free vertebra. Anal pterygiophores 6 , first one anterior to hemal spine of 23rd free vertebra. Two hypural ossifications on upper hypural plate, parahypural and hypurals one and two fused on lower plate. Procurrent caudal-fin rays 24 dorsally and 13 ventrally.

Color in preservative. Body pigmentation arranged in at least two different layers of integument. Deep layer composed of relatively large irregular dark spots of variable size and shape, larger and more concentrated on dorsum of trunk, gradually becoming more scattered and smaller on sides, entering dorsal surface of head only posteriorly and completely absent on ventral surface of trunk and head. A more superficially-located pattern of fine spots overlays large marking with relatively uniform freckle, densest on dorsum. Smaller superficial markings extend onto entire dorsal and lateral surfaces of head, as fine spots smaller than those on body, and form main component of dark pigmentation at that region. Sides of head slightly less heavily pigmented than dorsal region. Opercular patch of odontodes with pigmentation continuous with that on remainder of head. Odontode-bearing area of interopercle almost devoid of dark pigment, in contrast to area of head immediately dorsal to it. Upper lip with small spots similar to those on rest of head. Lower lip with small dark fields close to its anterior margin. Dorsal fin with irregular dark markings along its basal portion and anterior edge, with additional spots along rays on rest of fin, in some specimens aligned so as to form a poorlydefined stripe across the distal third of fin. Anal fin with dark pigmentation similar to that of dorsal fin, but generally fainter. Caudal fin covered with small irregular spots, often aligned to form one or more rough vertical lines across fin. Dorsal surface of pectoral fin with small dark markings similar to those on rest of flanks, fading distally to transparent margin. Pelvic fins mostly white, with only few dark chromatophores at base. Nasal barbels with irregular dark fields along entire length, on both surfaces. Maxillary and rictal barbels with dark markings mostly on dorsal surface.

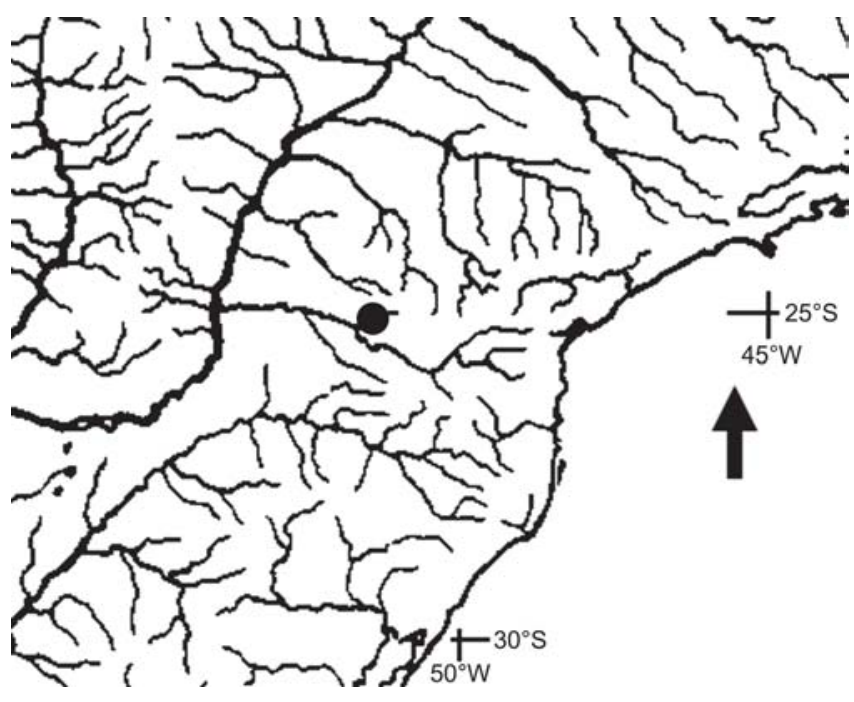

Fig. 3. Southern Brazil, showing approximate geographical distribution (black circle) of Trichomycterus igobi.

Distribution. Lower rio Jordão, close to its mouth on rio Iguaçu, rio Paraná drainage, Southern Brazil (Fig. 3)

Etymology. The species name igobi is based on a mythological character of the Tupi-Guarani Indian legend about the origin of the Iguaçu waterfalls.

Ecological data. Specimens of Trichomycterus igobi were collected in the same general locality as $T$. sp. C in the rio

Table 1. Morphometric data for holotype and paratypes (except MPEG 13354) of Trichomycterus igobi $(\mathrm{n}=10$ including the holotype).

\begin{tabular}{|c|c|c|c|}
\hline \multirow[b]{2}{*}{ Standard length $(\mathrm{mm})$} & \multirow{2}{*}{$\begin{array}{c}\text { Holotype } \\
(\mathrm{mm})\end{array}$} & \multicolumn{2}{|c|}{$\begin{array}{l}\text { Range } \\
(\mathrm{n}=10)\end{array}$} \\
\hline & & 62.0 & 90.1 \\
\hline \multicolumn{4}{|c|}{ Percents of standart length } \\
\hline Head length & 23.4 & 23.8 & 26.8 \\
\hline Predorsal length & 61.2 & 62.0 & 67.9 \\
\hline Prepelvic length & 58.1 & 60.3 & 64.6 \\
\hline Preanal length & 70.0 & 74.5 & 77.7 \\
\hline Scapular girdle width & 19.9 & 18.7 & 22.6 \\
\hline Trunk length & 36.7 & 37.6 & 41.8 \\
\hline Pectoral-fin length & 14.7 & 11.4 & 16.6 \\
\hline Pelvic-fin length & 9.8 & 8.7 & 12.1 \\
\hline Distance between pelvic-fin base and anus & 6.8 & 5.9 & 10.9 \\
\hline Caudal peduncle length & 16.2 & 15.4 & 19.7 \\
\hline Caudal peduncle depth & 14.8 & 16.0 & 19.0 \\
\hline Body depth & 19.4 & 17.2 & 24.9 \\
\hline Length of dorsal-fin base & 10.7 & 10.9 & 13.2 \\
\hline Length of anal-fin base & 7.0 & 6.8 & 8.7 \\
\hline \multicolumn{4}{|l|}{ Percents of head length } \\
\hline Head width & 95.3 & 79.4 & 95.3 \\
\hline Nasal barbel length & 34.6 & 29.9 & 40.9 \\
\hline Maxillary barbel length & 36.8 & 28.0 & 43.8 \\
\hline Rictal barbel length & 36.8 & 28.0 & 42.9 \\
\hline Snout length & 48.3 & 39.2 & 52.5 \\
\hline Interorbital & 29.9 & 20.9 & 29.9 \\
\hline Mouth width & 52.1 & 43.3 & 54.4 \\
\hline Eye diameter & 9.8 & 9.0 & 13.3 \\
\hline Supra-orbital pore distance & 6.8 & 6.3 & 10.8 \\
\hline
\end{tabular}


Jordão, and presumably occupy the same kind of fast water, rocky-substrate environment reported for that species ( $c f$. Wosiacki \& de Pinna, in press). The details of its microhabitat, however, are as yet unknown. The stomach of the cleared and stained specimen contained larvae of Diptera (Simulidae), Ephemeroptera, and Trichoptera, indicating benthic feeding habits.

\section{Discussion}

There is little doubt that closest relatives of T. igobi are to be found among other taxa now included in Trichomycterus. The new species shares all synapomorphies for the clade including all trichomycterids except Copionodontinae and Trichogeninae, while lacking those that support the distal group composed of Glanapteryginae, Sarcoglanidinae, Tridentinae, Stegophilinae and Vandelliinae (de Pinna, 1998). Taxa that fit neither of those clades are currently allocated in the Trichomycterinae, demonstrably non-monophyletic (Costa \& Bockmann, 1993; Wosiacki, 2002). Within that subfamily, T. igobi lacks the known synapomorphies for each of Bullockia, Eremophilus, Hacheria, Rhizosomichthys, and Scleronema (Arratia, 1990), Ituglanis (Costa \& Bockmann, 1993), and Silvinichthys (Arratia, 1998; Fernández \& de Pinna, 2005). That leaves the genus Trichomycterus as a default alternative for the inclusion of the new species. That genus is currently undiagnosable by synapomorphies and is the one that includes the majority of trichomycterine species. Despite that, we consider that the inclusion of the new species in Trichomycterus is the most reasonable course of action. We would not defend a new genus for T. igobi unless srictly required by phylogenetic criteria, which is not presently the case. Inclusion in Trichomycterus is further strengthened by evidence indicating that $T$. igobi is related to a subgroup of species currently allocated in that genus.

A set of concerted synapomorphies suggests that T. igobi may form a monophyletic group with two other species from the rio Iguaçu drainage, $T$. stawiarski and T. sp. C. In the description of the latter, Wosiacki \& de Pinna (in press) noted the peculiar morphology of the procurrent caudal fin rays in both $T$. sp. C and T. stawiarski. In those species, the individual procurrent caudal-fin rays are thickly ossified and rigid, with a fine distal tip, so that each of them resembles a small spinous structure. The same situation is present also in $T$. igobi. Such a condition of the procurrent rays is apomorphic, and contrasts markedly with the normal rays exhibited by all other trichomycterid outgroups, nematogenyids and most other catfishes with procurrent caudal-fin rays, where the rays are thin, flexible and hair-like.

Another character related to procurrent caudal-fin rays is also indicative of a close relationship between T. igobi, T. sp. C, and T. stawiarski. In the three species, the dorsal procurrent rays extend for a long portion of the caudal peduncle, stretching over the tips of at least ten neural spines. This is unusual in species of Trichomycterus, which normally have a shorter series of procurrent rays, extending for seven or eight neural spine tips. More basal trichomycterid outgroups have procurrent series shorter still, spanning between three and five neural spine tips. The closest values found among trichomycterines are those in $T$. mboycy (eight) and $T$. rivulatus (nine).

Branchiostegal ray counts also support a monophyletic group including $T$. igobi, $T$. sp. C, and T. stawiarski. The three species have increased numbers of branchiostegal rays, ten (rarely 11) in T. igobi and eleven in $T$. sp. C and $T$. stawiarski. Other trichomycterids usually have 5-8 rays, including phylogenetically basal copionodontines and trichogenines, as well as most species in Trichomycterus and other trichomycterines (T. castroi has 8-9, with a single specimen with ten on one side). More distant catfish outgroups, such as Nematogenys (Nematogenyidae) have more numerous branchiostegal rays. However, the taxonomic distribution of states within Trichomycteridae leaves little doubt that the plesiomorphic condition within the family is the possession of six to eight rays and that the increase to $10-11$ is apomorphic for subgroups therein. Wosiacki \& de Pinna (in press) noted some similarities in caudal peduncle depth and color pattern between $T$. sp. C and T. lewi, from Venezuela, and considered the possibility that the two species might be related. The latter species, however, has eight or nine branchiostegal rays (Lasso \& Provenzano, 2002: 1145), a condition which renders that potential relationship less likely.

None of the characters discussed above could be checked in all species currently included in Trichomycterus. Also, any inferences about relationships without a broad phylogenetic analysis remain hopelessly circumstantial. Our taxonomic sampling, however, allows the preliminary hypothesis of a monophyletic group composed of T. igobi, T. sp. C, and T. stawiarski. It is uncertain whether that clade belongs to the assemblage called "Trichomycterus brasiliensis species-complex" proposed by Barbosa \& Costa (2003) and later discussed by Bockmann \& Sazima (2004), comprising several species from the upper Paraná, upper São Francisco, Paraíba do Sul and Ribeira do Iguape. The evidence for that group is still ambiguous, as noted by Bockmann \& Sazima (2004: 72), and its limits and composition remain uncertain. A critical evaluation of its significance and potential implications for the clade herein recognized will have to await a more extensive comparative study.

Some uniquely derived features can be hypothesized as autapomorphies for T. igobi. The proportional size of its head, the largest in trichomycterids, is one of them which is unproblematic because of its uniqueness. Another is the reduced ossification of the second hypobranchial, which in $T$. igobi is restricted to a small vestigial crust on the anterolateral portion of the hypobranchial (Fig. 4), which remains mostly cartilaginous (its third hypobranchial is normally ossified according to the normal pattern in Trichomycterinae). In most other members of the Trichomycteridae, except for the 
Vandelliinae, Tridentinae and Stegophilinae, hypobranchial two has a well-defined conical ossification at its anterolateral corner, a plesiomorphic condition within the family. Arratia (1990) proposed the presence of a pronounced notch on the posteroventral margin of ceratobranchial 3 as a potentially derived character of the Trichomycterinae. The character is indeed present in many taxa previously assigned to the subfamily (but not in all of them, T. hasemani and T. johnsoni, for example, lack the ceratobranchial notch). A broader analysis of trichomycterid relationship (Wosiacki, 2002), however, has not corroborated the monophyly of Trichomycterinae, and the presence of the ceratobranchial notch is interpreted as homoplastic. Trichomycterus igobi lacks the noth, and its third ceratobranchial has a continuous posteroventral margin (Fig. 4).

The pectoral girdle in T. igobi is narrow and posteriorly concave, with a falciform shape which contrasts with the posteriorly convex or straight scapulocoracoid in other

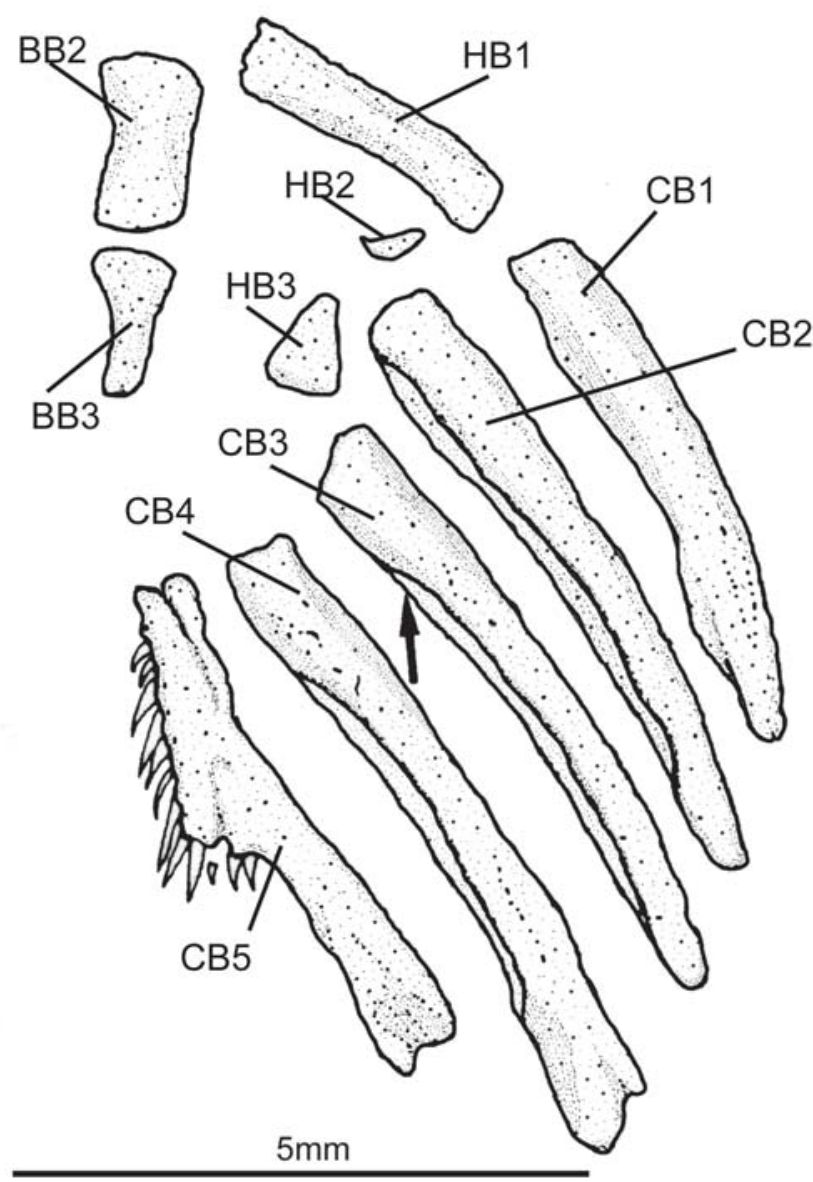

Fig. 4. Branchial skeleton of Trichomycterus igobi, MPEG 13354, paratype. Ventral view. Dorsal elements of gill arches and gill rakers not shown. Branchial cartilaginous structures not stained in this specimen. Abreviations: BB2-3, basibranchials 2 and 3; CB 1-5, ceratobranchials 1 to 5; HB13, hypobranchials 1 to 3 . Arrow indicates posteroventral margin of third ceratobranchial. trichomycterines and most remaining trichomycterids (Fig. 5). The plesiomorphic condition of the palatine of the Trichomycteridae is a rectangular bone with a postero-lateral process. In T. igobi a mesial expanded ossification at the articulation of palatine and lateral ethmoid is present (Fig. 6), a structure that is not present in others species of the family, and therefore is here hypothesized as an autapomorphy.
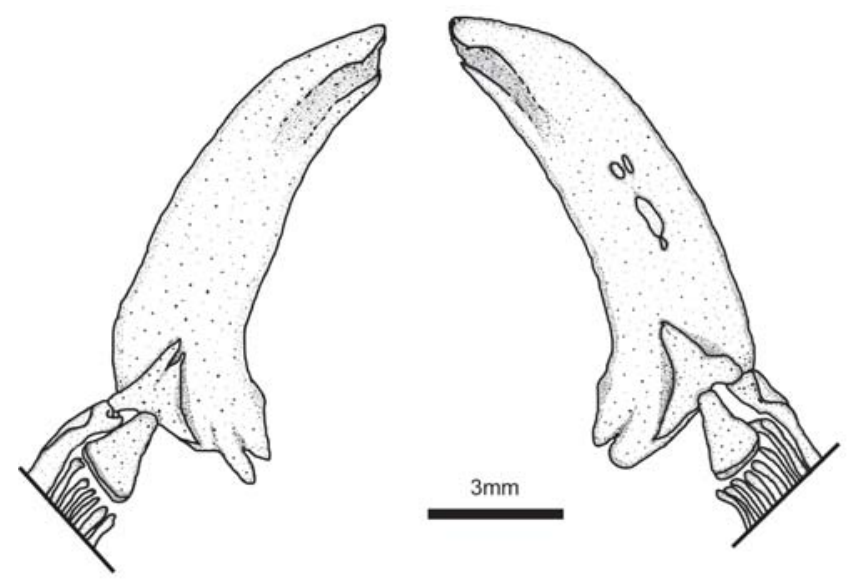

Fig. 5. Ventral view of the pectoral girdle in Trichomycterus igobi, MPEG 13354, paratype.

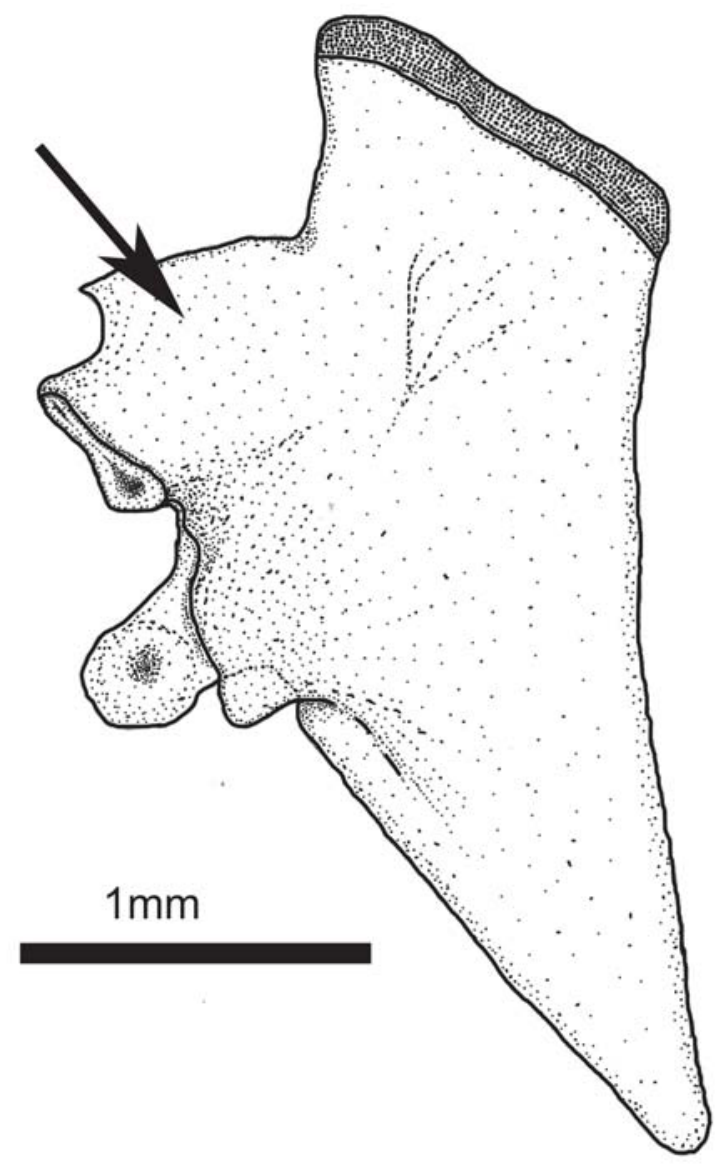

Fig. 6. Dorsal view of the right palatine of Trichomycterus igobi, MPEG 13354, paratype. Arrow indicates mesial bony expansion. 
Comparative material examined. Nematogenyidae: Nematogenys inermis; 1 (c\&s) UFRGS 3955. Trichomycteridae. Copionodontinae: Copionodon pecten, 6 (c\&s) MZUSP 42462. Trichogeninae: Trichogenes longipinnis, 3 (c\&s) MZUSP 63478. Trichomycterinae: Eremophilus mutisii, 1 (c\&s) MZUSP 35409 - 1 (c\&s) AMNH 56092; E. candidus (Paratypes), 5 (2 c\&s) MZUSP 11762; Trichomycterus n. sp. A, 7 (c\&s) MZUSP 25022; Trichomycterus n. sp. B, 2 MZUSP uncat.; Trichomycterus naipi MPEG 6699 (Holotype); (paratypes), 2 MZUSP 38788 - Trichomycterus papilliferus MPEG 6692 (Holotype); Trichomycterus mboycy (Holotype) MPEG 6695; Trichomycterus taroba MPEG 6689 (Holotype); Trichomycterus plumbeus MPEG 6686 (Holotype); T. nigricans, 1 (c\&s) MCP 10649; T. castroi, 1 (c\&s) MHNCI 7881 - 1 MHNCI 7643; T. iheringi, 8 (1c\&s) MHNCI 7916; T. davisi, 2 (c\&s) MCP 10646 - 34 MZUSP 38783; T. brasiliensis, 15 (2c\&s) MZUSP uncat.; T. mimonha, 4 MZUSP 34344 - 5 MCP 18021; T. stawiarski, 44 (3c\&s) MZUSP uncat.; T. rivulatus, 6 (1c\&s) ROM 403409; Bullockia maldonadoi, 1 (c\&s) MZUSP 36958; Hatcheria macraei, 2 (c\&s) MZUSP 35687; Scleronema minutum, 13 (c\&s) MCP 11169; S. operculatum, 1 (c\&s) MCP 9315; Ituglanis sp., 13 (5 c\&s) MNRJ 11489; Ituglanis proops, 7 MZUSP 36502 - 2 MUZSP 46902 - 2 MZUSP 39027.

\section{Acknowledgments}

The authors thank Vinicius Abilhôa (MHNCI) and Carla Pavanelli (NUP) for the loan of specimens. Research funding was provided by CNPq (Conselho Nacional de Desenvolvimento Científico e Tecnológico), FAPESP (Fundação de Amparo à Pesquisa do Estado de São Paulo), Lakeside Foundation (CAS), and PPBio (Programa de Pesquisa em Biodiversidade, Ministério da Ciência e Tecnologia, Brazilian government).

\section{Literature Cited}

Arratia, G., G. Chang, S. Menu-Marques \& G. Rojas. 1978. About Bullockia gen. nov., Trichomycterus mendozensis n. sp. and revision of the family Trichomycteridae. Studies on Neotropical Fauna and Environment, 13: 157-194.

Arratia, G. 1990. The South American Trichomycterinae (Teleostei: Siluriformes), a problematic group. Pp. 395-404. In: G. Peters $\&$ R. Hutterer (eds.). Vertebrates in the tropics. Museum Alexander Koenig, Bonn, Germany.

Arratia, G. 1998. Silvinichthys, a new genus of trichomycterid catfishes from the Argentinean Andes, with redescription of Trichomycterus nigricans. Ichthyological Exploration of Freshwaters, 9: 347-370.

Arratia, G. \& L. Huaquin. 1995. Morphology of the lateral line system and of the skin of diplomystid and certain primitive loricarioid catfishes and systematic and ecological considerations. Bonner Zoologische Monographien, 36: 1-110

Barbosa, M. A. \& W. J. E. M. Costa. 2003. Trichomycterus potschi (Siluriformes: Loricarioidei): a new trichomycterid catfish from coastal streams of southeastern Brazil. Ichthyological Exploration of Freshwaters, 14: 281-287.
Baskin, J. N. 1973. Structure and relationships of the Trichomycteridae. Unpublished Ph.D. Dissertation, City University of New York, New York. 389p.

Bockmann, F. A. \& I . Sazima. 2004. Trichomycterus maracaya, a new catfish from the upper rio Paraná, southeastern Brazil (Siluriformes: Trichomycteridae), with notes on the T. brasiliensis species-complex. Neotropical Ichthyology, 2: 61-74.

Costa, W. J. E. M. \& F. A. Bockmann. 1993. Un nouveau genre néotropical de la famille des Trichomycteridae (Siluriformes: Loricarioidei). Revue Française d'Aquariologie et Herpetologie, 20: $43-46$

Dingerkus, G. \& L. D. Uhler. 1977. Enzyme clearing of alcian blue stained whole small vertebrates. Stain Technology, 52: 229232.

Eigenmann, C. 1918. The Pygidiidae, a family of South American catfishes. Memoirs of the Carnegie Museum, 7: 259-398.

Fernández, L. \& M. C. C. de Pinna. 2005. Phreatic catfish of the genus Silvinichthys from southern South America (Teleostei, Siluriformes, Trichomycteridae). Copeia, 2005:100-108.

Lasso, C. A. \& F. Provenzano. 2002. Dos nuevas especies de bagres del género Trichomycterus (Siluriformes: Trichomycteridae) de la Gran Sabana, Escudo de las Guayanas, Venezuela. Revista de Biología Tropical, 50: 1139-1149.

de Pinna, M. C. C. 1998. Phylogenetic Relationships of Netropical Siluriformes (Teleostei: Ostariophysi); Historical overview and Synthesis of Hypotheses, p. 279-330: In L. R. Malabarba, R. E. Reis, R. P. Vari, Z. M. S. Lucena \& C. A. S. Lucena (Eds). Phylogeny and Classification of Neotropical Fishes. Porto Alegre, Edipucrs, 603p.

de Pinna, M. C. C. \& W. B. Wosiacki. 2003. Family Trichomycteridae (Pencil or parasitic catfishes). Pp. 270-290. In: Reis, R. E., S. O. Kullander, \& C. J. Ferraris (Org.). Check list of the freshwater fishes of South and Central America. Porto Alegre, Edipucrs, 729p.

Tchernavin, V. 1944. A revision of some Trichomycterinae based on material preserved in the British Museum (Natural History). Proceedings of the Zoological Society of London, 114: 234275.

Wosiacki, W. B. 2002. Estudo das relações filogenéticas de Trichomycterinae (Teleostei, Siluriformes, Trichomycteridae) com uma proposta de classificação. Unipublished Ph. D. Dissertation, Universidade de São Paulo, São Paulo. 324p.

Wosiacki, W. B. \& J. C. Garavello. 2004. Five new species of Trichomycterus from the rio Iguaçu (rio Paraná Basin) southern Brazil (Siluriformes: Trichomycteridae). Ichthyological Exploration of Freshwaters, 15: 1-16.

Wosiacki, W. B. \& M. C. C. de Pinna. 2007. Família Trichomycteridae: Trichomycterinae. Pp. 68-72. In: P. A. Buckup, N. A. Menezes \& M. S. A.Ghazzi (Eds).Catálogo das espécies de peixes de água doce do Brasil. Rio de Janeiro, Museu Nacional, $195 \mathrm{p}$.

Wosiacki, W. B. \& de Pinna, M. (in press). A new species of the Neotropical catfish genus Trichomycterus (Siluriformes: Trichomycteridae) representing a new body shape for the family. Copeia, 2008:

Accepted January 2008 Published 31 March 2008 